\title{
Thrombolysis: The Current State of The Art and How it can be Improved
}

\author{
Victor Gurewich* \\ Department of Medicine, USA
}

*Corresponding author: Victor Gurewich, Department of Medicine, Harvard Medical

School, Mount Auburn Hospital, USA.

Received Date: April 26, 2019

Published Date: May 03, 2019

\section{Mini Review}

Current thrombolytic therapy is essentially synonymous with high dose tPA administered iv for 90 minutes. This treatment has had only limited success in acute myocardial infarction (AMI) [1-3], and consequently has more recently been replaced by percutaneous coronary intervention (PCI) as the treatment of choice in AMI [4]. Although PCI delays coronary reperfusion, better clinical outcomes than with tPA were nevertheless obtained [5]. In the treatment of ischemic stroke, a tPA dose reduction was required due to a $20 \%$ intracranial hemorrhage (ICH) incidence when the AMI dose was used [6]. Dose reduction diminished the thrombolytic effect and resulted in a reperfusion rate of only about 30\% [7], and a 7\% incidence of symptomatic ICH remained [8]. As in AMI, PCI is now being used increasingly in stroke [JTT 9-11].

Historically, the use tPA for thrombolysis was based on the belief that IPA was responsible for intravascular fibrinolysis, whereas the other natural plasminogen activator, urokinase plasminogen activator (UPA), was responsible for extravascular fibrinolysis where its effect is mediated by its cell surface receptor, UPAR. Although this belief is rarely questioned, it is belied by a number of findings such as those from gene knockout animal studies. These showed that knocking out the uPA gene, but not the tPA gene, impairs lysis of a venous thrombus. The tPA gene knockout had little effect on thrombus resolution [12]. Similarly, a uPA but not a tPA knockout resulted in spontaneous fibrin formation, and UPA mediated fibrinolysis was not impaired by deletion of the UPAR gene [13], contrary to what had been believed. The tPA dominance concept was implicitly challenged also by the unexpected difficulty that was encountered to show that tPA was a better thrombolytic than streptokinase (SK), a non-specific, indirect, and inherently flawed plasminogen activator. An unprecedented total of 95,740 patients with AMI, in three mega-trials, were required to show a statistically significant difference [1-3]. Bayesian analysis of these findings suggested that "the clinical superiority of tPA over SK remains uncertain" [14].
Although there is little uPA in plasma, which reinforced the idea that it was an extravascular activator, there is a significant reservoir in blood found on platelets $[15,16]$ and monocytes [17]. It is also noteworthy that intravascular fibrinolysis is dependent on the activation of the three different fibrin-bound plasminogens [18], and only one of these is activated by tPA at a fibrin-specific doses [19]. The other two are activated by UPA, one by prouPA and the other by tcuPA [20-22]. Only at high non-specific doses can tPA activate these two plasminogens, and without its fibrin promotion, tPA is a poor plasminogen activator. These findings help explain the disappointing results obtained with tPA monotherapy. In addition, since tPA is an enzyme, it is also ill-suited for administration by infusion, and due to its high fibrin affinity, this may be unnecessary for its therapeutic effect. In biological fibrinolysis, tPA is stored in the vessel wall, and in the event of intravascular thrombus formation, it is released at that site, binds to the fibrin clot, and initiates thrombolysis. Lysis creates two new plasminogen binding sites on fibrin [23]. Plasminogen on one of these is activated specifically by prouPA [20,24] which is itself activated to tcuPA in the process [21], and tcuPA activates the remaining plasminogen [22]. Therefore, the two activators are complementary, with thrombolysis being initiated by tPA and completed by uPA [25]. Using tPA alone for thrombolysis is somewhat analogous to trying to run a car on the starting motor.

The activators are also synergistic [25] and this was once tested in a clinical study of 101 patients with AMI. Patients were given a mini-bolus of tPA (5 mg) followed by an infusion ( $40 \mathrm{mg} / \mathrm{h}$ ) of prouPA. A TMI-3 infarct artery patency of $60 \%$ was obtained, with no reocclusions or ICH and only a 1\% mortality [26], results which compare very favorably with the best of the tPA trials in AMI [3, 27]. Therefore, a small bolus of tPA, $5 \%$ of the standard dose, was sufficient in the presence of the other activator for exceptionally effective and safe thrombolysis, as also shown experimentally in vitro in the Figure below. Unfortunately, the above clinical study 
could not be followed up since prouPA commercial development was abandoned not long thereafter. This was because at the therapeutic doses required when used alone, prouPA became unstable in blood and converted to tcuPA, resulting in bleeding complications. To deal with this problem, a more stable, single site (Lys300 $\rightarrow$ His) mutant prouPA was developed which allows the physiological properties of prouPA to be preserved at therapeutic doses [28-38].

\section{Conclusion}

The longstanding concept that fibrinolysis is a function of tPA alone is based on a misunderstanding. Fibrinolysis, in fact, is dependent on the activities of both plasminogen activators, tPA and $\mathrm{UPA}$, which have complementary functions and are synergistic when combined. Their functions are sequential with tPA initiating fibrin degradation that is then completed by uPA. Since the latter has two functional forms, prouPA and tcuPA whereas tPA has one, UPA is responsible for two-thirds of fibrinolysis. The findings provide an explanation for the disappointing results obtained with tPA monotherapy, which has therefore been replaced by a timeconsuming catheterization procedure whenever possible.

\section{Acknowledgement}

None.

\section{Conflict of Interest}

No conflict of interest.

\section{References}

1. Gruppo Italiano Per Lo Studio Della Sopravvivenze Nell'Infarto Miocardico (1990) GISSI-2 A factorial randomised trial of alteplase versus streptokinase and heparin versus no heparin among 12,490 patients with acute myocardial infarction. Lancet 336: 65-71.

2. ISIS-3 Third International Study of Infarct Survival Collaborative Group (1992) ISIS-3: A randomised comparison of streptokinase vs tissue plasminogen activator vs anistreplase and of aspirin plus heparin vs aspirin alone among 41,299 cases of suspected acute myocardial infarction. The Lancet 339: 753-770.

3. The GUSTO Investigators (1993) An international randomized trial comparing four thrombolytic strategies for acute myocardial infarction. N Engl J Med 329: 673-682.

4. Keeley EC, Boura JA, Grines CL (2003) Primary angioplasty versus intravenous thrombolytic therapy for acute myocardial infarction: a quantitative review of 23 randomised trials. Lancet 361: 13-20.

5. Antman EM, Hand M, Armstrong PW, Bates ER, Green LA, et al. (2008) 2007 focused update of the ACC/AHA 2004 guidelines for the management of patients with ST-elevation myocardial infarction. Circulation 117: 296-329.

6. Boysen G and The ECASS Study Group (1995) European cooperative acute stroke study (ECASS): (rt-PA - thrombolysis in acute stroke) study design and progress report. Eur J Neurol 1: 213-219.

7. The National Institute of Neurological Disorders and Stroke rt-PA Stroke Study Group (1995) Tissue plasminogen activator for acute ischemic stroke. N Engl J Med 333: 1581-1587.

8. Sandercock P, Wardlaw JM, Lindley RI, Dennis M, Cohen G, et al. (2012) The benefits and harms of intravenous thrombolysis with recombinant tissue plasminogen activator within $6 \mathrm{~h}$ of acute ischemic stroke (the third international stroke trial [IST-3]: a randomized controlled trial. The Lancet 379: 2352-2363.

9. Campbell BCV, Mitchell PJ, Kleinig TJ, Helen M Dewey, Leonid Churilov, et al. (2015) Endovascular therapy for ischemic stroke with perfusionimaging selection. N Engl J Med 372: 1009-1018.
10. Berkhemer OA, Fransen PS, Beumer D, Vanden Berg LA, Lingsma HF, et al. (2015) A randomized trial of intraarterial treatment for acute ischemic stroke. N Engl J Med 372: 11-20.

11. Goyal M, Demchuk AM, Menon BK, Eesa M, Rempel JL, et al. (2015) Randomized assessment of rapid endovascular treatment of ischemic stroke. N Engl J Med 372: 1019-1030.

12. Singh I, Burnand KG, Collins M, Luttun A, Collen D, et al. (2003) Failure of thrombus to resolve in urokinase-type plasminogen activator geneknockout mice: rescue by normal bone marrow-derived cells. Circulation 107: 869-875

13. Bugge TH, Flick MJ, Danton MJ, Daugherty CC, Rømer J, et al. (1996) Urokinase-type plasminogen activator is effective in fibrin clearance in the absence of its receptor or tissue-type plasminogen activator. Proc Natl Acad Sci USA 93: 5899-5904.

14. Brophy JM, Joseph L (1995) Placing trials in context; GUSTO visited by Reverend Bayes. JAMA 273: 871-875.

15. Vaughan DE, Vautloutle E, Collen D (1990) Urokinase binds to platelets through a specific saturable, low affinity mechanism. Fibrinolysis 4: 141-146.

16. Gurewich V, Johnstone M, Loza JP, Pannell R (1993) Pro-urokinase and prekallikrein are both associated with platelets: implications for the intrinsic pathway of fibrinolysis and for therapeutic thrombolysis. FEBS Lett 318: 317-321.

17. Grau E, Moroz LA (1989) Fibrinolytic activity of normal human blood monocytes. Thromb Res 53: 145-162.

18. Suenson E, Lützen O, Thorsen S (1984) Initial plasmin-degradation of fibrin as the basis of a positive feed-back mechanism in fibrinolysis. Eur J Biochem 140: 513-522.

19. Hoylaerts M, Rijken DC, Lijnen HR, Collen D (1982) Kinetics of the activation of plasminogen by human tissue plasminogen activator. Role of fibrin. J Biol Chem 257: 2912-2929.

20. Liu J, Gurewich V (1992) Fragment E-2 from fibrin substantially enhances pro-urokinase-induced glu-plasminogen activation. A kinetic study using a plasmin-resistant mutant pro-urokinase (A-158-rpro-UK). Biochemistry 31: 6311-6317.

21. Petersen LC (1997) Kinetics of reciprocal pro-urokinase/plasminogen activation. Stimulation by a template formed by the urokinase receptor bound to poly (D-lysine). Eur J Biochem 245: 316-323.

22. Gurewich V (2015) Why so little progress in therapeutic thrombolysis? The current state of the art and prospects for improvement. J Thromb Thrombolysis 40: 480-487.

23. Harpel PC, Chang TS, Verderber E (1985) Tissue plasminogen activator and urokinase mediate the binding of Glu-plasminogen to plasma fibrin I. Evidence for new binding site in plasmin-degraded fibrin I. J Biol Chem 260: 4432-4440.

24. Liu J, Gurewich V (1991) A comparative study of the promotion of tissue plasminogen activator and pro-urokinase-induced plasminogen activation by fragments D and E-2 of fibrin. J Clin Invest 88: 2012-2017.

25. Pannell R, Black J, Gurewich V (1988) The complementary modes of action of tissue plasminogen activator (t-PA) and pro-urokinase (proUK) by which their synergistic effect on clot lysis may be explained. J Clin Invest 81: 853-859.

26. Zarich SW, Kowalchuk GJ, Weaver WD, Loscalzo J, Sassower M, et al. (1995) Sequential combination of thrombolytic therapy for acute myocardial infarction: results of the pro-urokinase and t-PA enhancement of thrombolysis (PATENT) trial. J Am Coll Cardiol 26: 374379.

27. Ross AM for the GUSTO Angiographic Investigators (1993) The effects of tissue plasminogen activator, streptokinase, or both on coronaryartery patency, ventricular function, and survival after acute myocardial infarction. N Engl J Med 329: 1615-1622.

28. Liu JN, Tang W, Sun ZY, Kung W, Pannell R, et al. (1996) A site-directed mutagenesis of pro-urokinase which substantially reduces its intrinsic activity. Biochemistry 35: 14070-14076. 
29. Sun Z, Jiang Y, Ma Z, Wu H, Liu BF, et al. (1997) Identification of a flexible loop (297-313) of urokinase-type plasminogen activator, which helps determine its catalytic activity. J Biol Chem 272: 23818-23823.

30. Tang W, Sun Z, Pannell R, Gurewich V, Liu J, et al. (1997) An efficient system for production of recombinant urokinase-type plasminogen activator. Protein Expr Purif 11: 279-283.

31. Sun Z, Liu BF, Chen Y, Gurewich V, Zhu D, et al. (1998) Analysis of the forces which stabilizes the active conformation of urokinase-type plasminogen activator. Biochemistry 37: 2935-2940.

32. Liu JN, Liu JX, Liu B, Sun Z, Zuo JL, et al. (2002) A prourokinase mutant which induces highly effective clot lysis without interfering with hemostasis. Circu Res 90: 757-763.

33. Gurewich V, Pannell R, Simmons Byrd A, Sarmientos P, Liu JN, et al. (2006) Thrombolysis versus bleeding from hemostatic sites by a prourokinase mutant compared with tissue plasminogen activator. J Thrombos Haemostas 4: 1559-1565.
34. Pannell R, Kung W, Gurewich V (2007) C1-inhibitor prevents non-specific plasminogen activation by a prourokinase mutant without impeding fibrin-specific fibrinolysis. J Thrombos Haemostas 5: 1047-1054.

35. Pannell R, Kung W, Gurewich V (2007) C1-inhibitor prevents non-specific plasminogen activation by a prourokinase mutant without impeding fibrin-specific fibrinolysis. J Thrombos Haemostas 5: 1047-1054.

36. Gurewich V, Pannell R (2009) Recombinant human C1-inhibitor prevents non-specific proteolysis by mutant prouPA during optimal fibrinolysis. Thrombos Haemostas 102(2): 279-286.

37. Tomasi S, Sarmientos P, Giorda G, Gurewich V, Vercelli A, et al. (2011) Mutant prourokinase with adjunctive C1-inhibitor is an effective and safer alternative to tPA in rat stroke. PLoS One 6: e21999.

38. Pannell R, Li S, Gurewich V (2015) Highly effective fibrinolysis by a sequential synergistic combination of mini-dose tPA plus low-dose mutant proUK. PLOS ONE 10(3): e122018. 